\title{
Retraction Note to: Hidrotische ektodermale Dysplasie
}

\section{Ein Fallbericht zweier Schwestern}

G. Komposch ${ }^{1}$ - W. v. Petrykowski ${ }^{1}$

Published online: 4 February 2016

(c) Springer-Verlag Berlin Heidelberg 2016

Retraction to: Fortschr. Kieferorthop. 39 (1978),

292-299

DOI 10.1007/BF02225787

This article is withdrawn by the publisher due to infringement of personal rights.

The online version of the original article can be found under doi:10.1007/BF02225787.

G. Komposch

gerda_komposch@med.uni-heidelberg.de

$1 \quad$ Kieferorthopädische Abteilung der Klinik und Poliklinik für

Zahn-, Mund- und Kieferkrankheiten der Universität Freiburg

i. Br., Hugstetter Straße 55, 7800 Freiburg im Breisgau,

Germany 